\title{
Two Unique Cases of Peritoneal Carcinomatosis Following Robotic Assisted Radical Prostatectomy
}

\author{
Robot Yardımlı Radikal Prostatektomi Sonrası Iki Nadir Peritoneal Karsinomatoz Olgusu
}

\author{
(D) Jacob Baber, (D) Tara McLaughlin, (D) Joseph Wagner, (D) Anoop Meraney \\ Hartford Hospital, Clinic of Urology, Hartford, USA
}

\begin{abstract}
We present two cases of peritoneal carcinomatosis following robotic assisted laparoscopic radical prostatectomy for prostate cancer. The first case is unique in that the carcinomatosis was found incidentally during a transperitoneal procedure for another malignancy. The patient did not possess high risk, adverse features and he experienced a 3-year period during which the prostate-specific antigen was undetectable. Our second case is unique in that, even though the patient had high risk disease, his margins were negative. It is possible that the transperitoneal nature of the surgeries may have contributed to the development of the metastases seen in these cases.
\end{abstract}

Keywords: Peritoneal carcinomatosis, Prostate cancer, Robot-assisted, Radical prostatectomy, Prostatectomy

Öz

Bu çalışmada, prostat kanserinde robot yardımlı laparoskopik radikal prostatektomi sonrasında gelişen iki peritoneal karsinomatoz olgusu sunmaktayız. Nadir olan ilk olgudaki karsinomatoz, başka bir malignite için transperitoneal işlem sırasında tesadüfen bulunmuştur. Hastada yüksek risk ve advers özellikler bulunmamaktaydı ve prostat spesifik antijenin saptanmadığı 3 yıllık bir süre deneyimlemiştir. Nadir olan ikinci olgunun hastalığı yüksek riskli olmasına rağmen, marjları negatifti. Ameliyatların transperitoneal doğası, bu olgularda görülen metastazların gelişimine katkıda bulunabilmektedir.

Anahtar Kelimeler: Peritoneal karsinomatoz, Prostat kanseri, Robot yardımlı, Radikal prostatektomi, Prostatektomi

\section{Introduction}

Peritoneal carcinomatosis from prostate cancer, with and without evidence of other metastatic sites, is extremely rare and not well studied. A handful of case reports describe dissemination at the time of cancer diagnosis as well as after treatment $(1,2,3,4,5,6)$. These presentations vary widely, with most patients presenting with new-onset malignant ascites. We report our experience of two cases presenting within a decade with peritoneal carcinomatosis following robotic-assisted laparoscopic radical prostatectomy for prostate cancer. Both offer unique insights into the prostate cancer disease process. This is not a research study. Neither patient underwent any experimental procedures. Patients provided consent for the standard of care treatments described here.

\section{Case Presentation}

The first case is a 65-year-old male who presented in 2006 with a prostate-specific antigen (PSA) level of $4.4 \mathrm{ng} / \mathrm{mL}$. He was diagnosed with Gleason 3+4 prostate cancer and underwent a robotic-assisted laparoscopic prostatectomy in July of 2006 with final pathology results indicating Gleason 3+4 disease, T2CNOMO and negative margins. He developed biochemical recurrence $(0.7 \mathrm{ng} / \mathrm{mL})$ in September 2009. Over the next year, repeat PSA measures revealed a rapid doubling time, peaking at $3.3 \mathrm{ng} / \mathrm{mL}$ in August 2010. Metastatic evaluation was negative. He was subsequently started on androgen deprivation therapy (ADT) after which his PSA measures remained $<0.1 \mathrm{ng} / \mathrm{mL}$ for several years. In June 2014, we started him on intermittent ADT. In December 2016, his PSA was $3.05 \mathrm{ng} / \mathrm{mL}$ with ADT being held. Repeat metastatic evaluation with computed tomography (CT)

Correspondence: Tara McLaughlin, Hartford Hospital, Clinic of Urology, Hartford, USA

Phone: +1 8609722662 E-mail: tara.mclaughlin@hhchealth.org ORCID-ID: orcid.org/0000-0001-9841-9843

Received: 07.12 .2018

Accepted: 31.12 .2018

Cite this article as: Baber J, McLaughlin T, Wagner J, Meraney A. Two Unique Cases of Peritoneal Carcinomatosis Following Robotic Assisted Radical

Prostatectomy. J Urol Surg 2019;6(2):152-155.

๑Copyright 2019 by the Association of Urological Surgery / Journal of Urological Surgery published by Galenos Publishing House. 
scan of the abdomen, pelvis and bone revealed an incidental enhancing $2.3 \mathrm{~cm}$ right renal mass, which grew to $2.7 \mathrm{~cm}$ over the next 10 months. Biopsy of the mass revealed renal cell carcinoma, clear cell type. The patient was scheduled for a robotic-assisted laparoscopic partial nephrectomy in September 2017. After access was gained into the peritoneum and pneumoperitoneum established, the initial laparoscopy revealed several small white lesions throughout the abdomen and pelvis, particularly conjugated around the right hemidiaphragm (Figure 1). The lesions were biopsied and sent to pathology for frozen section analysis. The main concerns at that time were peritoneal seeding from the biopsy of the renal mass and prostate adenocarcinoma. Upon receipt of the pathology report revealing prostate adenocarcinoma, the procedure was aborted. The final pathology revealed peritoneal carcinomatosis of metastatic prostate adenocarcinoma, Gleason $4+4=8$. PSA prior to initiation of therapy was $6.6 \mathrm{ng} / \mathrm{mL}$. In October 2017, the patient began therapy with ADT+ abiraterone/prednisone. His PSA as of December 2017 was $0.2 \mathrm{ng} / \mathrm{mL}$.
Our second case involves a 65-year-old man diagnosed in 2007 with Gleason 4+4 (grade group 4) prostate cancer in 3/12 cores with a PSA of $2.7 \mathrm{ng} / \mathrm{mL}$. He underwent a robotic-assisted laparoscopic prostatectomy with pelvic lymph node dissection

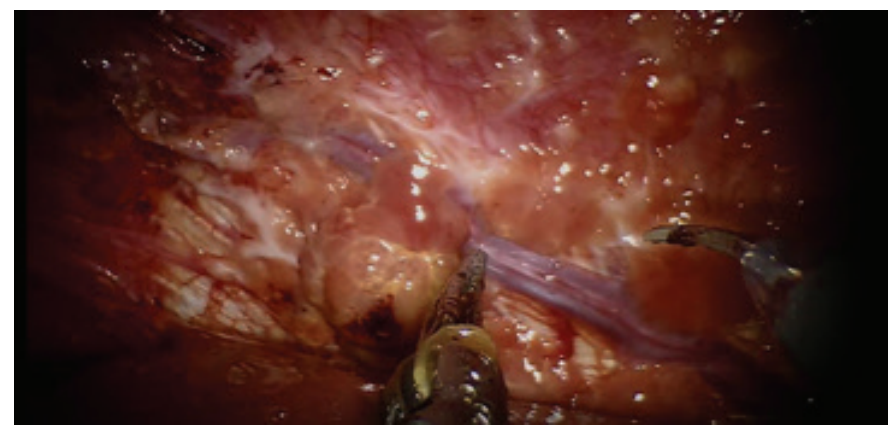

Figure 1. Peritoneal implants located underneath the diaphragm (case 1) Initial laparoscopy as part of planned robotic assisted laparoscopic partial nephrectomy revealed the several small white lesions pictured here, seen throughout the abdomen and pelvis, particularly conjugated around the right hemi-diaphragm.

Table 1. Summary of reported cases of peritoneal metastasis of prostate cancer

\begin{tabular}{|c|c|c|c|c|c|c|c|}
\hline Authors & $\begin{array}{l}\text { Age at } \\
\text { diagnosis }\end{array}$ & $\begin{array}{l}\text { Gleason score } \\
\text { (grade group) }\end{array}$ & $\begin{array}{l}\text { Initial PSA } \\
(\mathrm{ng} / \mathrm{mL})\end{array}$ & $\begin{array}{l}\text { PSA at } \\
\text { time of } \\
\text { recurrence }\end{array}$ & Initial TNM & $\begin{array}{l}\text { Treatment before } \\
\text { detection of } \\
\text { metastasis }\end{array}$ & $\begin{array}{l}\text { Treatment after } \\
\text { detection of metastasis }\end{array}$ \\
\hline $\begin{array}{l}\text { Kehinde et al. } \\
\text { (4) } 2002\end{array}$ & 76 & 4+4 (group 4) & 365 & 365 & T3N0M1 & - & Bilateral orchiectomy \\
\hline $\begin{array}{l}\text { Brehmer et } \\
\text { al. (7) } 2007\end{array}$ & 75 & $4+5$ (group 5) & 42 & 42 & T3N0M1 & - & ADT \\
\hline $\begin{array}{l}\text { Zagouri et al. } \\
\text { (8) } 2009\end{array}$ & 75 & 4+5 (group 5) & 33 & 74 & TxNOMO & ADT & Docetaxol \\
\hline $\begin{array}{l}\text { Benedict et } \\
\text { al. (2) } 2010\end{array}$ & 67 & 4+4 (group 4) & 36.4 & 82 & pT1a/bN0M0 & TURP, ADT & Docetaxol \\
\hline $\begin{array}{l}\text { Hiyama et al. } \\
\text { (3) } 2011\end{array}$ & 69 & $4+4$ (group 4) & 9.5 & 168 & $\begin{array}{l}\text { T3aNOM0, } \\
\text { +margin }\end{array}$ & LRP, Salvage XRT, ADT & Palliation \\
\hline $\begin{array}{l}\text { Shin et al. (5) } \\
2012\end{array}$ & 75 & 4+3 (group 3) & 10.5 & 12.37 & $\begin{array}{l}\text { pT3aNOM0, } \\
\text { +margin }\end{array}$ & RALP + PLND & $\begin{array}{l}\text { Surgical resection of } \\
\text { peritoneal/liver lesion }\end{array}$ \\
\hline $\begin{array}{l}\text { Talwar, et al. } \\
\text { (9) } 2012\end{array}$ & 59 & $3+4$ (group 2) & 54.6 & 54.6 & TxN0M1 & - & ADT \\
\hline $\begin{array}{l}\text { Labanaris et } \\
\text { al. (10) } 2013\end{array}$ & 62 & $5+4$ (group 5) & 13.3 & 13.3 & $\mathrm{cT} 2 \mathrm{cNOMO}$ & $\begin{array}{l}\text { - (aborted RALP due to } \\
\text { discovery of implants) }\end{array}$ & ADT \\
\hline $\begin{array}{l}\text { Acar et al. (1) } \\
2014\end{array}$ & 77 & 5+4 (group 5) & 6.8 & 1.2 (on ADT) & $\begin{array}{l}\text { pT3aNoM0, } \\
\text { +margin }\end{array}$ & RALP + PLND, ADT & $\begin{array}{l}\text { Continued on ADT, Excision } \\
\text { of port site recurrence, } \\
\text { abiraterone, scheduled for } \\
\text { chemotherapy }\end{array}$ \\
\hline $\begin{array}{l}\text { Petrakis et al. } \\
\text { (11) } 2015\end{array}$ & 76 & Unknown & Unknown & 286.4 & Unknown & TURP, ADT & Docetaxol \\
\hline $\begin{array}{l}\text { Sheng et al. } \\
\text { (6) } 2017\end{array}$ & 61 & $3+4$ (group 2) & 9.5 & 11.4 & Unknown & $\begin{array}{l}\text { RALP (unknown PLND), } \\
\text { salvage XRT + ADT }\end{array}$ & $\begin{array}{l}\text { ADT, omentectomy, } \\
\text { abiraterone }\end{array}$ \\
\hline Case 1 & 65 & $3+4$ (group 2) & 4.4 & 6.6 & $\begin{array}{l}\text { pT2cNOM0, } \\
\text {-margin }\end{array}$ & $\begin{array}{l}\text { RALP + PLND, } \\
\text { iADT for BCR }\end{array}$ & ADT + abiraterone \\
\hline Case 2 & 65 & 4+5 (group 5) & 2.7 & $\begin{array}{l}93.9 \text { (on } \\
\text { ADT) }\end{array}$ & $\begin{array}{l}\text { pT3bNoM0, } \\
\text {-margin }\end{array}$ & $\begin{array}{l}\text { RALP + PLND, salvage } \\
\text { XRT for BCR, ADT }\end{array}$ & $\begin{array}{l}\text { Therapeutic paracentesis, } \\
\text { docetaxel, mitoxantrone, } \\
\text { cabazitaxel }\end{array}$ \\
\hline
\end{tabular}

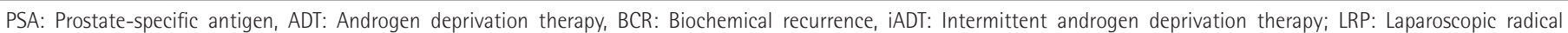
prostatectomy, PLND: Pelvic lymph node dissection, RALP: Robot assisted laparoscopic prostatectomy, TURP: Transurethral resection of the prostate, XRT: Radiotherapy 
in June 2007. Results of pathology indicated Gleason $4+5$, T3bNOMO, with negative margins. In January 2008, the patient experienced a biochemical recurrence of $0.2 \mathrm{ng} / \mathrm{mL}$, for which he received external beam radiation and ADT after which the PSA became undetectable. In 2009, the PSA began to rise again to $1.8 \mathrm{ng} / \mathrm{mL}$ in August and $2.4 \mathrm{ng} / \mathrm{mL}$ in September. Metastatic evaluation was negative. Six months later, his PSA had risen to $93.9 \mathrm{ng} / \mathrm{mL}$ and he was complaining of significant increase in his abdominal girth. He was admitted and underwent a staging work-up including CT of the chest, abdomen, and pelvis, which revealed pulmonary and mesenteric nodules. Therapeutic paracentesis of the ascitic fluid revealed adenocarcinoma consistent with prostate cancer. ADT was initiated. In April, 2010, he started to receive docetaxel, but repeat scans showed disease progression in the mesentery and he was transitioned to mitoxantrone in July of that year. Once again, repeat scans showed radiographic progression and the patient was started on cabazitaxel in September. Unfortunately, the metastatic disease burden continued to progress despite chemotherapy, and the patient was transitioned to hospice care in December, 2010.

\section{Discussion}

We are the first to report two cases of metastatic peritoneal carcinomatosis of prostate cancer from a high-volume single institution. Table 1 compares our cases to previous cases from the literature $(1,2,3,4,5,6,7,8,9,10,11)$. Our cases are unique in several ways. Our first case did not possess high risk, adverse features. His PSA was $<10$ with pathology indicating grade group $2,<\mathrm{pT} 3$, and negative margins. In addition, the carcinomatosis was found incidentally during a transperitoneal procedure for another malignancy. Standard imaging algorithms failed to detect these implants, and it is not known how often this occurs. However, with the advent of improved imaging technology, such as F-18 fluciclovine or prostate-specific membrane antigen positron emission tomography/computed tomography scans, it is possible that these occurrences will be better detected in the future. Our second case is unique relative to prior case reports in that, even though the patient had-high risk disease, his margins were negative.

Both of our cases demonstrate the heterogeneity of the disease process in terms of metastatic presentation and disease progression. The reasons underlying the metastasis are likely multifactorial and include tumor-related factors, such as highrisk, high-grade cancer. While transperitoneal surgery may be a factor in the development of peritoneal metastasis, it can occur as a presenting symptom or after non-transperitoneal procedures such as transurethral resection of the prostate $(4,11,12)$. Nonetheless, both of our cases had negative margins, and even one of our patients had $<\mathrm{T} 3$ disease, suggesting that the transperitoneal nature of the surgery may have contributed to the development of the metastasis.

\section{Conclusion}

Isolated peritoneal metastasis is a rare presentation of metastatic prostate cancer. These two cases represent unique contributions to the literature: one had low-risk pathologic features with negative margins while the other had high-risk features, again with negative margins. The transperitoneal approach for prostate surgery may be a significant factor contributing to peritoneal metastasis as well as to the underlying tumor biology. Peritoneal carcinomatosis is known to be associated with several intra-abdominal malignancies and now needs to be considered in patients with advanced prostate cancer.

\section{Ethics}

Informed Consent: Patients provided consent for the standard of care treatments described here.

Peer-review: Externally peer-reviewed.

\section{Authorship Contributions}

Surgical and Medical Practices: J.B., J.W., A.M., Concept: J.B., J.W., A.M., Design: J.B., J.W., A.M., Data Collection and/or Processing: J.B., J.W., A.M., Analysis and/or Interpretation: J.B., J.W., A.M., T.M., Literature Search: J.B., J.W., A.M., T.M., Writing: J.B., J.W., A.M., T.M.

Conflict of Interest: No conflict of interest was declared by the authors.

Financial Disclosure: Dr. Joseph Wagner's Covidien served as a consultant on the Genomic Health Advisory Board.

\section{References}

1. Acar Ö, Esen T, Bavbek S, Peker Ö, Musaoğlu A. Port site and peritoneal metastases after robot-assisted radical prostatectomy. Int J Surg Case Rep 2014;5:131-134.

2. Benedict SP, Ahuja M, Mammen KJ. Hormone refractory carcinoma prostate with peritoneal metastases and malignant ascites without skeletal involvement: A case report and review of literature. Indian J Urol 2010;26:287-288.

3. Hiyama $Y$, Kitamura H, Takahashi S, Masumori N, Shindo T, Tsujiwaki M, Mitsuhashi T, Hasegawa T, Tsukamoto T. Peritoneal dissemination of prostate cancer due to laparoscopic radical prostatectomy: a case report. J Med Case Rep 2011;5:355.

4. Kehinde EO, Abdeen SM, Al-Hunayan A, Ali Y. Prostate cancer metastatic to the omentum. Scand J Urol Nephrol 2002;36:225-227.

5. Shin YS, Doo AR, Kim MK, Jeong YB, Kim HJ. First case of peritoneal seeding of prostate cancer during robot-assisted laparoscopic radical prostatectomy. Can J Urol 2012;19:6303-6305.

6. Sheng J, Findley TW, Sadeghi-Nejad H. Isolated non-ascitic peritoneal carcinomatosis from metastatic prostate cancer. Urol Case Rep 2017;10:14-15. 
7. Brehmer B, Makris A, Wellmann A, Jakse G. [Solitary peritoneal carcinomatosis in prostate cancer]. Aktuelle Urol 2007;38:408-409.

8. Zagouri F, Papaefthimiou M, Chalazonitis AN, Antoniou N, Dimopoulos MA, Bamias A. Prostate cancer with metastasis to the omentum and massive ascites: a rare manifestation of a common disease. Onkologie 2009;32:758761.

9. Talwar M, Self SE, Ullian ME. Prostate cancer metastatic to the peritoneum in a peritoneal dialysis patient. Perit Dial Int 2012;32:570-2.

10. Labanaris AP, Zugor V, Pokupic S, Afram S, Witt JH. Peritoneal dissemination of prostate cancer with the absence of lymph node, skeletal, or visceral metastases in a patient scheduled to undergo robot-assisted radical prostatectomy. J Robot Surg 2013;7:201-204.

11. Petrakis D, Pentheroudakis G, Kamina S, Pappa L, Papadiotis E, MalamouMitsi V, Pavlidis N. An unusual presentation of a patient with advanced prostate cancer, massive ascites and peritoneal metastasis: Case report and literature review. J Adv Res 2015;6:517-521.

12. Megalli MR, Gursel EO, Veenema RJ. Ascites as an unusual presentation of carcinoma of the prostate. J Urol 1973;110:232-234. 